\title{
Effect of replacing soybean meal by urea on performance, carcass characteristics and meat quality of housed Saanen young goats
}

José Luiz Leonardo de Araujo Pimenta ${ }^{1} \oplus$, Carlos Alberto da Silva Filho²®, Karine Bellas Romariz de Macedo² Rafaella da Rocha Olivieri de Barros ${ }^{2} \odot$, Júlia dos Santos Fonseca ${ }^{2} \oplus$, Arléia Medeiros Maia ${ }^{\circledR}$, Sabrina Luzia Gregio de Sousa ${ }^{2} \oplus$, Rodrigo Vasconcelos de Oliveira ${ }^{2}$

\footnotetext{
1 Universidade Estadual Paulista, Faculdade de Ciências Agrárias e Veterinárias, Jaboticabal, SP, Brasil. E-mail: luiz.pimenta@unesp.br

${ }^{2}$ Universidade Federal Rural do Rio de Janeiro, Seropédica, RJ, Brasil. E-mail: camusrj@gmail.com; karinebellas@gmail.com; rafaela.zoo@gmail.com; julia.agropecuaria@yahoo.com.br; arleiamedeirosmaia2017@gmail.com; sgregio@hotmail.com; oliveirarvetal@gmail.com
}

ABSTRACT: The aim of this study was to evaluate the effect of replacing soybean meal by urea in the diet of housed Saanen young goats on performance, carcass and meat characteristics. Eighteen Saanen young males were used, with an initial average weight of $21.68 \pm 0.83 \mathrm{~kg}$ for the treatment with soybean meal and $20.89 \pm 0.61 \mathrm{~kg}$ for the treatment with urea, distributed in a completely randomized design. The total weight gain and the slaughter weight, as well as the carcass and commercial cuts yield were not altered by the replacement of soybean meal with urea $(p>0.05)$. However, there was less fasting weight loss in the diet containing urea $(p=0.01)$. The meat quality characteristics were also not changed by the total substitution of soybean meal for urea $(p>0.05)$. The replacement of soybean meal with urea does not compromise the performance, carcass characteristics and the meat quality of housed Saanen young goats.

Key words: carcass yield; commercial cuts; morphometric measurements; non-protein nitrogen; rib-eye area

\section{Efeito da substituição do farelo de soja pela ureia sobre o desempenho e características da carcaça e qualidade da carne de cabritos Saanen confinados}

RESUMO: O objetivo deste estudo foi avaliar o efeito da substituição do farelo de soja pela ureia na dieta de cabritos Saanen sobre o desempenho, características da carcaça e da carne. Foram utilizados 18 machos inteiros, da raça Saanen, com peso médio inicial de 21,68 $\pm 0,83 \mathrm{~kg}$ para o tratamento com farelo de soja e 20,89 $\pm 0,61 \mathrm{~kg}$ para o tratamento com ureia, distribuídos em delineamento inteiramente casualizado. 0 ganho de peso total e o peso ao abate, assim como o rendimento de carcaça e dos cortes comerciais não foram alterados pela substituição do farelo de soja pela ureia $(p>0.05)$. Entretanto, houve menor perda de peso por jejum na dieta contendo ureia $(p=0,01)$. As características de qualidade da carne também não foram alteradas pela substituição total do farelo de soja por ureia $(p>0.05)$. A substituição do farelo de soja pela ureia não compromete o desempenho, as características da carcaça e a qualidade da carne de cabritos Saanen terminados confinados.

Palavras-chave: cortes comerciais; medidas morfométricas; nitrogênio não-proteico; rendimento de carcaça; área de olho de costela 


\section{Introduction}

The meat goat production is a relatively new activity in Brazil and different factors can affect its efficiency, however, animal feeding is one of the main production costs. In this context, the use of forage protein supplement, like soybean meal, increases diet cost on goat production (Mendes et al., 2010). Therefore, non-protein nitrogen (NPN) sources (NPN), for instance urea, have been used as an alternative to meet protein requirements in ruminants (Kawas et al., 2010).

The efficiency on growing male goats provide future bucks and young slaughtered animals. Moreover, goat meat is a high biological value food with less fat than beef (Gama et al., 2020). Considering the male limited contribution on dairy production systems and the cost of growing male goats, the urea, as an NPN source, is a viable alternative to enhance financial return in dairy goat systems. Nevertheless, there is a lack of studies regarding the feeding urea impacts on performance, carcass and meat quality in goats. Therefore, our objective was to evaluate the substitution of soybean meal by urea on diet of house young male Saanen goats and its effects on performance, carcass characteristics and meat quality.

\section{Materials and Methods}

The study was conducted at the goat production facility at the Federal Rural University of Rio de Janeiro in Seropédica RJ, from January to May. The Committee of Ethics in Animal Use (CEUA/IZ/UFRRJ) approved the protocols used in this research under the registration number 0008-06-2018.

Eighteen intact male Saanen goats with 150 days of age were randomly divided in two groups: control (CG) and urea (UG). All animals were disbudded, dewormed with levamisole hydrochloride $(3.75 \mathrm{mg} / \mathrm{kg})$ and kept in two collective pens with $15 \mathrm{~m}^{2}$, respectively.

The experimental design was completely randomized, with two treatments and nine, replicates in each treatment. Two isoproteic diets with $12 \%$ CP containing 50:50 roughage: concentrate based on dry matter (DM), composed by $50 \%$ DM of Tifton 85 hay (Cynodon spp.) and 50\%DM of concentrate, without urea in the control group or 1\%DM of urea in the urea group. All concentrate was based on crushed corn, soybean meal, and minerals following recommendations of National Research Council (NRC, 2007) to meet requirements for 150 g daily gain (Table 1 ).

The Tifton hay, crushed corn and the soybean meal were evaluated for dry matter (DM) and crude protein (CB) (Detmann et al., 2012) in the Laboratory of Bromatology at the Department of Pasture and Animal Nutrition - UFRRJ (UFRRJ/IZ).

The diet was provided twice a day, at 8 a.m and $5 \mathrm{p} . \mathrm{m}$ and leftover feed was weighted daily using a digital scale, in order to maintain a $20 \%$ leftover feed and estimate dry matter consumption.

Each animal group was adapted for 14 days to the diet, respectively. After the adaptation period, all animals were
Table 1. Composition of experimental diets (\%DM).

\begin{tabular}{lcc}
\hline \multicolumn{1}{c}{ Ingredients } & Control & Urea \\
\hline Tifton 85 hay & 50.00 & 50.00 \\
Crushed corn & 41.40 & 47.00 \\
Soybean meal & 6.60 & - \\
Urea (\%MS) & - & 1.00 \\
Calcitic lime (\%MS) & 1.50 & 1.50 \\
Dicalcium phosphate (\%MS) & 0.50 & 0.50 \\
\hline \multicolumn{1}{c}{ Nutrients composition } & & \\
\hline Dry matter & 88.24 & 88.09 \\
Crude protein & 12.31 & 12.29 \\
Total digestive nutrients & 66.31 & 65.90 \\
Neutral digestive fiber & 45.63 & 45.37 \\
\hline
\end{tabular}

weighted weekly using a mechanic platform before diet offer (Açores ${ }^{\circ}, 602$ SM model, Cambé-PR). The experimental period was 121 days and the goats were slaughtered with ages varying from 263 to 286 days.

For slaughter, the animals were submitted to a 14-hour fast and slaughter live weight (SLW) was obtained. The slaughtering followed the Brazilian RIISPOA (Brasil, 2017) with a stunning by captive dart pistol followed by bleeding, withdrawal head, leg and tail with skinning and evisceration.

Carcasses were divided by using a hand saw and weighed to obtain hot carcass weight (HCW). Following this procedure, carcasses were cooled to $2-4^{\circ} \mathrm{C}$ for 24 hours and weighted to obtain cold carcass weight (CCW). The carcass $\mathrm{pH}$ was measured at 30 min of slaughter $\left(\mathrm{pH}_{\mathrm{i}}\right)$ and after 24 hours cooling at $4^{\circ} \mathrm{C}\left(\mathrm{pH}_{\mathrm{f}}\right)$, by using a digital pHmeter (WTW', Model 300i, Berlin, Germany).

Carcasses were measured using a tape measure, in order to evaluate: external carcass length (ECL): distance from tail base to neck base; internal carcass length (ICL): distance from pubis symphysis to medial point of the internal portion of first rib; Leg length (LL): distance from perineum to ventral portion of tarsus; Leg circumference (LC) was obtained in the middle portion of the hind leg. Additionally, using a measuring stick other two measures were obtained: Leg thickness (LT): measured in the middle point of hind leg and Hip width (HW): the distance between greater trochanters;

The previous measurements were used to calculate carcass compacity index $(\mathrm{CCl})\left(\mathrm{kg} \mathrm{cm}^{-1}\right)$ and leg compacity index $(\mathrm{LCl})$, by the Equations 1, 2 and 3.

$$
\mathrm{CCI}=\frac{\mathrm{CCW}}{\mathrm{ICL}}
$$

where: $\mathrm{CCl}=$ carcass compacity index; $\mathrm{CCW}=$ cold carcass weight and $\mathrm{ICL}=$ internal carcass length .

$$
\mathrm{LCI}=\frac{\mathrm{HW}}{\mathrm{LL}}
$$

where: $\mathrm{LCl}=$ leg compacity index; $\mathrm{HW}=$ hip width and $\mathrm{LL}=$ leg length.

Besides, fast loss weight (FLW) (\%) weas calculated. 


$$
\mathrm{FLW}=\left[\frac{\left(\mathrm{LW}_{\text {before fast }}-\mathrm{LW}_{\text {after fast }}\right)}{\mathrm{LW}_{\text {before fast }}}\right] \cdot 100
$$

Regarding the calculation of hot carcass yield (\%) (HCY), cold carcass yield (\%) (CCY) and cooling weight loss (\%) (CWL), by the Equations 4,5 and 6 .

$$
\operatorname{HCY}(\%)=\left(\frac{\mathrm{HCW}}{\mathrm{SBW}}\right) \cdot 100
$$

where: $\mathrm{HCY}=$ hot carcass weight; $\mathrm{HCW}=$ hot carcass weight and SBW = slaughter body weight.

$$
\operatorname{CCY}(\%)=\left(\frac{\mathrm{CCW}}{\mathrm{SBW}}\right) \cdot 100
$$

where: $\mathrm{CCY}=$ cold carcass weight; $\mathrm{CCW}=$ cold carcass weight and SBW = slaughter body weight.

$$
\operatorname{CWL}(\%)=\frac{(\mathrm{HCW}-\mathrm{CCW})}{\mathrm{HCW}} \cdot 100
$$

where: $\mathrm{CWL}=$ cooling weight loss; $\mathrm{HCW}=$ hot carcass weight and $\mathrm{CCW}=$ cold carcass weight .

After 24 hours of cooling at $2-4^{\circ} \mathrm{C}$, carcasses were separated in six cuts: Neck: cut between the last cervical vertebra and the first thoracic vertebra; Shoulder: cut between the axillary region and the scapula and humerus; Ribs: cut between the last cervical vertebra and the first thoracic vertebra, cut between the last thoracic vertebra and the first lumbar vertebra and cut the ribs $8 \mathrm{~cm}$ from the spine; Braes: cut in a straight line from the thorax to flank, around $8 \mathrm{~cm}$ from the spine; Loin: cut between the last thoracic vertebra and the first lumbar vertebra and cut between the last lumbar vertebra and the first sacral vertebra; Leg: cut between the last lumbar vertebra and the first sacral vertebra. All the six cuts were weighed and their individual yields as carcass percentage were calculated.

Posteriorly, in order to evaluate the rib-eye area, a cut between the $12^{\text {th }}$ and $13^{\text {th }}$-thoracic vertebrae was processed to expose a transversal section of Longissimus dorsi muscle. Over this transversal section of $L$. dorsi was allocated a graduated transparent sheet to obtain its area (Osório et al., 1998).

The loin cuts from all animals were frozen for physical measurements of meat quality. After thawing, the loin cuts were processed for physical analysis of thawing weight loss, color, cooking weight loss and shear force, in triplicate (Monte et al., 2007). The physical color analysis was performed using a spectrophotometer (Hunterlab ${ }^{\circ}$, MiniScan EZ model), which measured the luminosity (\%) $\left(L^{*}\right)$, red level $\left(a^{*}\right)$ and yellow level ( $\left.b^{*}\right)$.

The cooking lost weight (CLW) (\%) was measured using muscle fragments $(3.0 \times 4.0 \times 2.5 \mathrm{~cm})$, which were weighed and grilled at $170^{\circ} \mathrm{C}$ until the center of the meat reached $71^{\circ} \mathrm{C}$. After grilling, all meat pieces were cooled to room temperature and weighed.
After CLW analysis, the same samples were used to evaluate shear force $\left(\mathrm{Kgf.cm}^{-2}\right)$. For each meat fragment, a cylinder fragment with $1.2 \mathrm{~cm}^{2}$ of diameter was obtained and, subsequently, evaluated by the Texture Analyzer (TA-XT plus ${ }^{\circ}$ )

Statistical analysis was performed using the GraphPad PRISM $5^{\circ}$ software. The data normality was evaluated by D'Agostino-Pearson test. Differences between treatments (CG vs UG) were analyzed by $t$ test for parametrical data and Mann-Whitney for non-parametrical data. The statistical model is presented in the Equation 7.

$$
Y i j=m+T i+e i j
$$

where: $Y_{i j}=$ variable value; $j=$ unit; $I=$ treatment (soybean meal or urea); $\mathrm{m}=$ overall mean effect; $\mathrm{Ti}=$ treatment effect; eij $=$ error term of the jth unit receiving ith treatment.

\section{Results and Discussion}

The soybean meal substitution by urea on Saanen male goat feeding did not affect animal performance $(p>0.05)$ (Table 2). The control and urea groups reach similar final body weights of $37.39 \pm 0.92 \mathrm{~kg}$ and $35.42 \pm 1.87 \mathrm{~kg}$, respectively $(p>0.05)$, suggesting that urea can replace soybean meal without compromising performance. In fact, Saanen goat breed is considered a big and heavy breed, with bucks weighing from 70 to $90 \mathrm{~kg}$ and young goats with desirable weight gain, explaining the obtained performance from the isoproteic diets.

The fasting weight loss was higher in the control group than in the urea group (CG: $5.08 \pm 0.61$ vs UG: $4.05 \pm 0.33$ ) ( $p$ $<0.05$ ) (Table 2). Fasting weight is considered one of the most efficient ways to body weight evaluation, because it avoids differences of gastrointestinal tract content caused by feed source and feeding system (Yáñez et al., 2007). Considering these facts, animals with high level consumption could present greater pass tax, and, consequently, superior fasting lost (Dias et al., 2011). The current mean results from fasting weight loss observed are similar to another previous goat study by Safari et al. (2009).

\begin{tabular}{|c|c|c|c|}
\hline \multirow{2}{*}{ Parameters } & \multicolumn{2}{|c|}{ Treatments } & \multirow{2}{*}{$p$ value } \\
\hline & Control & Urea & \\
\hline Initial live weight, kg & $21.68 \pm 0.83$ & $20.89 \pm 0.61$ & 0.45 \\
\hline Final live weight, kg & $37.49 \pm 0.92$ & $35.42 \pm 1.87$ & 0.35 \\
\hline Slaughter body weight, kg & $36.56 \pm 0.96$ & $34.39 \pm 1.76$ & 0.14 \\
\hline Fasting weight loss, $\%$ & $5.08 \pm 0.61 a$ & $4.05 \pm 0.33 b$ & 0.01 \\
\hline Hot carcass weight, kg & $17.24 \pm 0.41$ & $16.33 \pm 0.97$ & 0.39 \\
\hline Hot carcass dressing, $\%$ & $47.23 \pm 072$ & $47.37 \pm 0.82$ & 0.90 \\
\hline Cold carcass weight, kg & $16.72 \pm 0.34$ & $15.72 \pm 0.90$ & 0.31 \\
\hline Cold carcass dressing $\%$ & $45.84 \pm 0.69$ & $45.64 \pm 0.60$ & 0.84 \\
\hline Cooling weight loss, $\%$ & $2.93 \pm 0.59$ & $3.57 \pm 0.82$ & 0.54 \\
\hline
\end{tabular}

Carcass characteristics did not differ between treatments $(p>0.05)$. Additionally, slaughter weight, hot and cold carcass

Table 2. Performance and carcass characteristics of Saanen goat fed with diets containing urea replacing soybean meal. 
weights and dressing were also similar between treatments $(p>0.05)$ (Table 2). Results of hot and cold carcass dressing in control and urea group, were related to previous goat study which observed from 43.3 to $49.0 \%$ and from 42.3 to $46.8 \%$, respectively (Pereira Filho et al., 2008).

Cooling weight loss (CWL) did not differ between diet treatments (CG: $2.93 \pm 0.59$ vs UG: $3.57 \pm 0.82$ ) ( $p>0.05$ ). Najafi et al. (2012) observed a cooling weight loss of $2.2 \%$ by feeding goats with diet enriched by oil sources, which was lower than the results found it this study. Cooling weight loss is higher in carcass with lower fat cover score and in light animals carcass weighing less than $35 \mathrm{~kg}$ (Webb et al., 2005).

The rib-eye area is a muscle development indicative (Yakan et al., 2016). The replacement of soybean meal by urea did not significantly influence rib-eye area (CG: $12.11 \pm$ $0.63 \mathrm{~cm}^{2}$ vs UG: $\left.12.67 \pm 0.41 \mathrm{~cm}^{2}\right)$ and both groups presented satisfactory results $(p>0.05$ ) (Table 3). Similarly, Grande et al. (2009) evaluating rib-eye area on Saanen $x$ Boer goats verified a mean of $13.77 \mathrm{~cm}^{2}$.

We did not observe differences of carcass morphometric parameters between control and urea groups $(p>0.05)$. Bone development measurements, represented by external and internal carcass lengths and leg length, are direct related with animal growth rate (Queiroz et al., 2015). As we did not observe changes for these measurements, urea can be reasonably used for growing goats without development impairs. Our results of internal carcass length are related with a previous study by Yanez et al. (2004), which observed values from 56.90 to $68.20 \mathrm{~cm}$ in Saanen goats.

Additionally, hip width was similar between the two groups (CG: $13.29 \pm 0.14$ vs $13.74 \pm 0.23$ ) ( $p>0.05)$. In Saanen goats, this measurement is mainly associated with bone development and less with muscle growing (Yanez et al., 2004). Our hip width results were similar to previous studies that verified values of hip width around $14 \mathrm{~cm}$ for Saanen goats (Yáñez et al. 2004; Bolacali \& Kucuk, 2012).

It was not observed differences on leg thickness (CG: 7.64 \pm 0.34 vs UG: $7.50 \pm 0.21$ ) and circumference (CG: $31.11 \pm$ 0.64 vs UG: $30.72 \pm 2.41)(p>0.05)$ between control and urea groups. Although carcass leg measurements are common in bovine studies, there is a lack of goat studies using these evaluations.

Table 3. Carcass morphometric measurements of Saanen goat fed with diets containing urea replacing soybean meal.

\begin{tabular}{lccc}
\hline \multirow{2}{*}{\multicolumn{1}{c}{ Parameters }} & \multicolumn{2}{c}{ Treatments } & \multirow{2}{*}{ p value } \\
\cline { 2 - 4 } & Control & Urea & \\
\hline External carcass length, $\mathrm{cm}$ & $77.00 \pm 1.76$ & $76.11 \pm 2.21$ & 0.76 \\
Internal carcass length, $\mathrm{cm}$ & $68.28 \pm 0.65$ & $68.33 \pm 1.40$ & 0.97 \\
Leg length, $\mathrm{cm}$ & $40.56 \pm 0.43$ & $39.00 \pm 0.97$ & 0.14 \\
Hip width, $\mathrm{cm}$ & $13.29 \pm 0.14$ & $13.74 \pm 0.23$ & 0.06 \\
Leg thickness, $\mathrm{cm}$ & $7.64 \pm 0.34$ & $7.50 \pm 0.21$ & 0.72 \\
Leg circumference, $\mathrm{cm}$ & $31.11 \pm 0.64$ & $30.72 \pm 2.41$ & 0.70 \\
Carcass compacity, $\mathrm{kg} \mathrm{cm}^{-1}$ & $0.13 \pm 0.01$ & $0.11 \pm 0.01$ & 0.10 \\
Leg compacity index & $0.33 \pm 0.01$ & $0.33 \pm 0.03$ & 0.95 \\
Rib-eye area, $\mathrm{cm}^{2}$ & $12.11 \pm 0.63$ & $12.67 \pm 0.41$ & 0.47 \\
\hline
\end{tabular}

Carcass compacities were similar between the treatments (CG: $0.13 \pm 0.01$ vs UG: $\left.0.11 \pm 0.01 \mathrm{~kg} \mathrm{~cm}^{-1}\right)(p>0.05)$. It is worth highlighting that carcass compacity expresses carcass musculature and Saanen goats presents lower levels.

Leg compacity index is an efficiency parameter of leg meat proportion. Animals from both groups presents uniform leg compacity index results (CG: $0.33 \pm 0.01$ vs UG: $0.33 \pm 0.03$ ) $(p>0.05)$ (Table 3 ). Heavy animals with short legs usually present superior compacity leg index.

We did not observe differences between treatments for any of the commercial cuts (neck, shoulder, ribs, braes, loin, and leg) weights and yields ( $p>0.05$ ) (Table 4). The goat commercial cuts results found in this study are similar to another goat study, developed by Grande et al. (2003), using Saanen breed with equivalent age and weight.

The total percentage of shoulder, loin and leg cuts was around $62.5 \%$ of carcass in both treatments and did not differ between treatments $(p>0.05)$ (Table 4). The shoulder and leg were the heaviest cuts, weighing on average $2.69 \mathrm{~kg}$ and $1.70 \mathrm{~kg}$ with $33.11 \%$ and $20.17 \%$ of the carcass, respectively. Should and leg together usually overcome $50 \%$ of carcass and are the best to predict carcass tissue composition. Moreover, leg play the major contribution to carcass weight, because of its superior meat yield.

The ribs cut is highly valued, reaching high market prices. (Costa et al., 2011). In this study, ribs and leg together represent an average of about $49 \%$ of the carcass weight, regardless of the treatment. The weights and yields from carcass cut obtained in this study confirm the carcass quality of Saanen goat fed with urea.

It was not confirmed a difference between the control and urea group concerning meat quality characteristics: luminosity, red level, yellow level, $\mathrm{pH}$, thawing loss, cooking loss and shear force $(p>0.05)$ (Table 5$)$. The meat colour parameters luminosity $\left(L^{*}\right)$, red level $\left(a^{*}\right)$ and yellow level $\left(b^{*}\right)$ did not express myoglobin changes between both groups. Higher red level values indicate red tones close to yellow region and lower red level values indicate red tones close to

Table 4. Weight and yield of carcass cuts of Saanen goat fed with diets containing urea replacing soybean meal.

\begin{tabular}{|c|c|c|c|}
\hline \multirow{2}{*}{ Cuts } & \multicolumn{2}{|c|}{ Treatments } & \multirow{2}{*}{ p value } \\
\hline & Control & Urea & \\
\hline \multicolumn{4}{|c|}{ Cut weights, kg } \\
\hline Neck & $0.87 \pm 0.04$ & $0.80 \pm 0.06$ & 0.31 \\
\hline Shoulder & $1.63 \pm 0.10$ & $1.78 \pm 0.01$ & 0.23 \\
\hline Ribs & $1.23 \pm 0.09$ & $1.36 \pm 0.05$ & 0.28 \\
\hline Braes & $0.85 \pm 0.07$ & $0.98 \pm 0.04$ & 0.12 \\
\hline Loin & $0.68 \pm 0.06$ & $0.69 \pm 0.03$ & 0.88 \\
\hline Leg & $2.61 \pm 0.15$ & $2.77 \pm 0.06$ & 0.34 \\
\hline \multicolumn{4}{|c|}{ Cut yields, $\%$} \\
\hline Neck & $11.05 \pm 0.04$ & $9.54 \pm 0.06$ & 0.31 \\
\hline Shoulder & $20.71 \pm 0.10$ & $21.24 \pm 0.01$ & 0.23 \\
\hline Ribs & $15.63 \pm 0.09$ & $16.20 \pm 0.05$ & 0.28 \\
\hline Braes & $10.80 \pm 0.07$ & $11.68 \pm 0.04$ & 0.12 \\
\hline Loin & $8.64 \pm 0.06$ & $8.22 \pm 0.03$ & 0.88 \\
\hline Leg & $33.16 \pm 0.15$ & $33.06 \pm 0.06$ & 0.34 \\
\hline
\end{tabular}


Table 5. Meat quality characteristics of Saanen goat fed with diets containing urea replacing soybean meal.

\begin{tabular}{|c|c|c|c|}
\hline \multirow{2}{*}{ Parameters } & \multicolumn{2}{|c|}{ Treatments } & \multirow{2}{*}{$p$ value } \\
\hline & Control & Urea & \\
\hline Luminosity, (L*) & $42.95 \pm 0.68$ & $42.20 \pm 0.79$ & 0.54 \\
\hline Red level, $\left(a^{*}\right)$ & $11.82 \pm 0.36$ & $12.30 \pm 0.21$ & 0.27 \\
\hline Yellow level, (b*) & $12.87 \pm 0.12$ & $12.60 \pm 0.33$ & 0.96 \\
\hline $\mathrm{pH}$ & $5.53 \pm 0.01$ & $5.55 \pm 0.02$ & 0.64 \\
\hline Thawing loss, $\%$ & $3.33 \pm 0.59$ & $3.08 \pm 0.30$ & 0.71 \\
\hline Cooking loss, $\%$ & $20.26 \pm 0.83$ & $18.39 \pm 0.75$ & 0.11 \\
\hline Shear force, $\mathrm{Kgf} \mathrm{cm}^{-2}$ & $3.00 \pm 0.22$ & $2.76 \pm 0.09$ & 0.32 \\
\hline
\end{tabular}

gray region (Madruga et al., 2009). Higher superior red (a*) and yellow ( $b^{*}$ ) levels, 19.58 and 14.25 , were obtained by Madruga et al. (2003) studying meat quality in Saanen goats. The yellow level $\left(b^{*}\right)$ usually determines the yellow intensity which is influenced by beta-carotene in muscle fat. Meat from extensive system animals shows a darker color, because exercises increase heme pigment concentration in muscle (Diaz et al., 2002). In the current study, the goats were kept housed, therefore with less exercises the meat was lighter. The current results support that replacing soybean meal with urea did not affect the physical meat quality based on color.

The $\mathrm{pH}$ is a relevant factor on muscle transformation to meat with effect on meat quality. Moreover, the meat acidity has a direct influence on meat texture and color. Our meat $\mathrm{pH}$ results are related with the range from 5.4 to 5.8 observed by Marinova et al. (2001) in goat meat.

Representing the meat tenderness, the shear force, did not differ significantly between treatments (CG: $3.00 \pm 0.22$ vs UG: $2.76 \pm 0.09)(p>0.05)$. In addition, the cooking loss was also not influenced by urea on the goat diet (CG: $20.26 \pm 0.83$ vs UG: $18.39 \pm 0.75)(p>0.05)$ with values close to reported by Salles et al. (2013). As a quality measured, cooking loss is influenced by meat water retention capacity and is related to yield meat after preparing for consumption (Monte et al., 2012). Intense cooking loss is present in inferior quality meat with lower $\mathrm{pH}$, common in pale, soft and exudative meat (PSE meat). In the current study, all animals from both treatments, soybean meal or urea, present desirable meat physical quality traits.

\section{Conclusion}

The total replacement of soybean meal by urea on diets of housed Saanen young goats does not affect performance, carcass characteristics and physical meat quality.

\section{Acknowledgments}

The authors would like to thank the Goat Production Facility Team of the Federal Rural University of Rio de Janeiro for all assistance during the experiment. The current study was developed with support of the Coordination for the Improvement of Higher Education Personnel (CAPES).

\section{Literature Cited}

Bolacali, M.; Kucuk, M. Various body measurements of Saanen kids. YYU Veteriner Fakultesi Dergisi, v.23, n.1, p.23-28, 2012. http://vfdergi.yyu. edu.tr/archive/2012/23-1/2012_23_(1)_23-28.pdf. 19 Mar. 2020.

Borges, G. D. S.; Macedo, V. P.; Baiffus, F. S. B.; Atoji, K.; Hill, J. A. G.; Batista, R.; Bianchi, A. E.; Ortiz, S. Desenvolvimento ponderal e biométrico de caprinos lactentes com acesso ao creep feeding em diferentes idades. Revista Brasileira de Saúde e Produção Animal, v.14, n.4, p.745-754, 2013. https://doi.org/10.1590/S1519-99402013000400018

Brasil. Ministério da Agricultura, Pecuária e Abastecimento. Decreto № 9013, de 29 de março de 2017. Regulamenta a Lei no 1.283, de 18 de dezembro de 1950, e a Lei no 7.889, de 23 de novembro de 1989, que dispõem sobre a inspeção industrial e sanitária de produtos de origem animal. Diário Oficial da União, v. 154, n. 62, seção 1, p.3-27, 2017. Brasília: Ministério da Agricultura, Pecuária e Abastecimento, 2017. http://www.agricultura.gov.br/assuntos/ inspecao/produtos-animal/arquivos/decreto-n-9013-2017_altdecreto-9069-2017_pt.pdf/view. 25 Mar. 2020.

Costa, R. G.; Santos, N. M. S.; Sousa, W. H.; Queiroga, R. C. R. E.; Azevedo, P. S.; Cartaxo, F. Q. Qualidade física e sensorial da carne de cordeiros de três genótipos alimentados com rações formuladas com duas relações volumoso:concentrado. Revista Brasileira de Zootecnia, v.40, n.8, p.1781-1787, 2011. https://doi. org/10.1590/S1516-35982011000800023.

Detmann, E.; Souza, M. A.; Valadares Filho, S. C.; Queiroz, A. C.; Berchielli, T. T.; Saliba, E. O. S.; Cabral, L. S.; Pina, D. S.; Ladeira, M. M.; Azevedo, J. A. G. Métodos para análise de alimentos. Visconde do Rio Branco: Suprema, 2012. 214p.

Dias, R. S.; Patino, H. O.; López, S.; Prates, E.; Swanson, K. C.; France, J. Relationships between chewing behavior, digestibility and digesta passage kinetics in steers fed restricted and ad libitum levels of oat hay. Journal of Animal Science, v.1, n.1, p.18731880, 2011. https://doi.org/10.2527/jas.2010-3156.

Díaz, M. T.; Velasco, S.; Cañeque, V.; Lauzurica, S.; Ruiz de Huidobro, F. Use of concentrate or pasture for fattening lambs and its effect on carcassand meat quality. Small Ruminant Research, v.43, n.1, p.257268, 2002. https://doi.org/10.1016/S0921-4488(02)00016-0

Gama, K. V. M. F.; Pereira Filho, J. M.; Soares, R. F.; Cordão, M. A.; Cézar, M. F.; Batista, A. S. M.; Silva, A. M. A.; Madruga, M. S.; Oliveira, R. L.; Bezerra, L. R. Fatty acid, chemical, and tissue composition of meat comparing Santa Inês breed sheep and Boer crossbreed goats submitted to different supplementation strategies. Tropical Animal Health and Production, v.52, p.601-610, 2020. https:// doi.org/10.1007/s11250-019-02047-1.

Gomes, H. F. B.; Menezes, J. J. L.; Gonçalves, H. C.; Cãnizares, G. I. L.; Medeiros, B. B. L.; Neto, A. P.; Lourençon, R. V.; Chávari, A. C. T. Características de carcaça de caprinos de cinco grupos raciais criados em confinamento. Revista Brasileira de Zootecnia, v.2, n.1, p.411417, 2011. https://doi.org/10.1590/S1516-35982011000200024.

Grande, P. A.; Alcalde, C. R.; Lima, L. S.; Ayer, I. M.; Macedo, F. A. F.; Matsushita, M. Características quantitativas da carcaça e qualitativas do músculo Longissimus dorsi de cabritos $3 / 4$ Boer $+1 / 4$ Saanen confinados recebendo rações contendo grãos de oleaginosas. Revista Brasileira de Zootecnia, v.38, n.1, p.11041113, 2009. https://doi.org/10.1590/S1516-35982009000600019. 
Grande, P. A.; Alcalde, C. R.; Macedo, F. A. F.; Yamamoto, S. M.; Nunes, M. E. Desempenho e características de carcaça de cabritos da raça Saanen recebendo rações com farelo de glúten de milho e/ou farelo de soja. Acta Scientiarum, v.25, n.2, p.315321, 2003. https://doi.org/10.4025/actascianimsci.v25i2.2012.

Kawas, J. R.; Andrade-Montemayor, H.; Lu, C. D. Strategic nutrient supplementation of free-ranging goats. Small Ruminant Research, v.89, n.1, p.234-243, 2010. https://doi.org/10.1016/j. smallrumres.2009.12.050.

Madruga, M. S.; Medeiros, E. J. L. M.; Sousa, W. H.; Cunha, M. G. G.; Pereira Filho, J. M.; Queiroga, R. C. R. E. Chemical composition and fat profile of meat from crossbred goats reared under feedlot systems. Revista Brasileira Zootecnia, v.38, n.3, p.547-552, 2009. https://doi.org/10.1590/S1516-35982009000300021.

Madruga, M. S.; Souza, J. G.; Arruda, S. G. B.; Narain, N. Carne caprina de animais mestiços: estudos do perfil aromático. Ciência e Tecnologia de Alimentos, v.23, n.3, p.323-329, 2003. https://doi. org/10.1590/S0101-20612003000300005

Marinova, P.; Banskalieva, V.; Alexandrov, S.; Tzvetkova, V.; Stanchev, $H$. Carcass composition and meat quality of kids fed sunflower oil supplemented diet. Small Ruminant Research, v. 42, n. 3, p. 219227, 2001. https://doi.org/10.1016/S0921-4488(01)00245-0.

Mendes, C. Q.; Fernandes, R. H. R.; Susin, I.; Pires, A. V.; Gentil, R. S. Substituição parcial do farelo de soja por ureia ou amireia na alimentação de cabras em lactação. Revista Brasileira de Zootecnia, v.39, n.8, p.1818-1824, 2010. https://doi.org/10.1590/ S1516-35982010000800026.

Monte, A. L. S.; Selaive-Villarroel, A. B.; Garruti, D. S.; Zapata, J. F. F.; Borges, A. S. Parâmetros físicos e sensoriais de qualidade da carne de cabritos mestiços de diferentes grupos genéticos. Food Science and Technology, v.27, n.2, p.233-238, 2007. https://doi. org/10.1590/S0101-20612007000200004

Monte, A. L. S.; Gonsalves, H. R. O.; Selaive-Villarroel, A. B.; Damaceno, M. N.; Cavalcante, A. B. D. Qualidade da carne de caprinos e ovinos: uma revisão. Revista Agropecuária Científica no Semiárido, v.8, n.1, p.11-17, 2012. http://revistas.ufcg.edu. br/acsa/index.php/ACSA/article/viewFile/161/pdf. 19 Mar. 2020.

Najafi, M. H.; Zeinoaldini, S.; Ganjkhanlou, M.; Mohammad, H.; Hopkins, D. L.; Ponnampalan, E. N. Performance, carcass traits, muscle fatty acid composition and meat sensory properties of male Mahabadi goat kids fed palm oil, soybean oil or fish oil. Meat Science, v.92, n.4, p.848-854, 2012. https://doi.org/10.1016/j. meatsci.2012.07.012.

National Research Council - NRC. Nutrient Requirements of Small Ruminants: Sheep, Goats, Cervids, and New World Camelids. Washington: National Academy Press, 2007. 384p.
Osório, J.C.S.; Osório M.T.M.; Jardim, P.O.C. Métodos para avaliação de carne ovina "in vivo" na carcaça e na carne. Pelotas: Ed. UFPEL, 1998. 107p.

Pereira Filho, J. M.; Resende, K. T.; Teixeira, I. A. M. A.; Silva Sobrinho, A. G.; Yáñez, E. A.; Ferreira, A. C. D. Características da carcaça e alometria dos tecidos de cabritos F1 Boer $\times$ Saanen. Revista Brasileira de Zootecnia, v.37, n.5, p.905-912, 2008. https://doi. org/10.1590/S1516-35982008000500019.

Queiroz, L. O.; Santos, G. R. A.; Macêdo, F. A. F.; Mora, N. H. A. P.; Torres, M. G.; Santana, T. E. Z.; Macêdo, F. G. Características de carcaça de cordeiros Santa Inês, abatidos com diferentes espessuras de gordura subcutânea. Revista Brasileira de Saúde e Produção Animal, v.16, n.3, p.712-722, 2015. https://doi. org/10.1590/S1519-99402015000300021.

Safari, J.; Mushi, D. E.; Mtenga, L. A.; Kifaro, G. C.; Eik, L. O. Effects of concentrate supplementation on carcass and meat quality atributs of feedlot finished small East African goats. Livestock Science, v.125, n.2, p.266-274, 2009. https://doi.org/10.1016/j livsci.2009.05.007.

Salles, F. M.; Zambom, M. A.; Alcalde, C. R.; Macedo, F. A. F.; Souza, R.; Gomes, L. C.; Dias, F. B.; Molina, B. S. L. Características de carcaça de cabritos criados em dois sistemas de terminação. Arquivo Brasileiro de Medicina Veterinária e Zootecnia, v.65, n.6, p.1867-1875, 2013. https://doi.org/10.1590/S010209352013000600039.

Webb, E. C.; Casey, N. H.; Simela, L. Goat meat quality. Small Ruminant Research, v.60, n.1, p.153-166, 2005. https://doi.org/10.1016/j smallrumres.2005.06.009.

Yakan, A.; Ates, C. T.; Alasahan, S.; Odabasioglu, F.; Unal, N.; Ozturk, O. H.; Gungor, O. F.; Ozbeyaz, C. Damascus kids' slaughter, carcass and meat quality traits in different production systems using antioxidant supplementation. Small Ruminant Research, v.136, p.43-53, 2016. https://doi.org/10.1016/j smallrumres.2016.01.002.

Yáñez, E. A.; Resende, K. T.; Ferreira, A. C. D.; Medeiros, A. N.; Silva Sobrinho, A.G.; Artoni, S. M. B. Effests of feed restriction on yield, retail cuts and tissue composition of carcass of Saanen kids. Revista Brasileira de Zootecnia, v.36, n.3, p.666-673, 2007. https://doi.org/10.1590/S1516-35982007000300021.

Yáñez, E. A.; Resende, K. T.; Ferreira, A. C. D.; Medeiros, N. A.; Silva Sobrinho, A. G.; Pereira Filho, J. M.; Teixeira, I. A. M A.; Artoni, S. M. B. Utilização de Medidas Biométricas para Predizer Características da Carcaça de Cabritos Saanen. Revista Brasileira de Zootecnia, v.33, n.6, p.1564-1572, 2004. https://doi org/10.1590/S1516-35982004000600024. 